\title{
Identification of a novel hydrolase encoded by $h y-1$ from Bacillus amyloliquefaciens for bioremediation of carbendazim contaminated soil and food
}

\author{
Ying Li, Miaomiao Chi, Xizhen Ge* \\ (Beijing Key Laboratory of Biomass Waste Resource Utilization, Biochemical Engineering College, \\ Beijing Union University, Beijing 100023, China)
}

\begin{abstract}
Carbendazim (MBC) is an effective antifungal and antibacterial pesticide in agricultural applications. However, the MBC-contaminated soil and food are difficult to be restored. In this work, a novel MBC-hydrolase HY-1 encoded by gene hy-1 from an isolated MBC-degrading bacteria Bacillus amyloliquefaciens has been screened and identified. The 858 bp hydrolase gene was expressed in E. coli BL21 and the $32 \mathrm{kDa}$ hydrolase HY-1 was purified. The purified HY-1 was able to catalyze MBC into 2-aminobenzimidazole (2-AB) without the need for any cofactors. Then bioremediation experiment was conducted and both the strain Car4 and cell crude extract of E. coli (pET-hyl) accelerated MBC degradation in soil. Moreover, purified HY-1 was available in removing MBC residue on the surface of cucumber. This work explored the possibility of microbial and enzymatic bioremediation on MBC-contaminated soil and food, provide a new way for bioremediation of pesticide contaminations.
\end{abstract}

Keywords: carbendazim, bioremediation, antifungal and antibacterial pesticide, hydrolase, soil, food, pesticide contamination DOI: $10.25165 /$ j.ijabe.20191202.4190

Citation: Li Y, Chi M M, Ge X Z. Identification of a novel hydrolase encoded by hy-1 from Bacillus amyloliquefaciens for bioremediation of carbendazim contaminated soil and food. Int J Agric \& Biol Eng, 2019; 12(2): 218-224.

\section{Introduction}

Carbendazim (MBC) is one of the most effective compounds of benzimidazole fungicide applied in preventing fungal plant diseases in crops ${ }^{[1,2]}$. Moreover, it is also the degradation product of the other benzimidazole fungicides such as benomyl or thiophanatemethy $\mathrm{l}^{[3]}$. However, MBC is a stable compound with a long half-life period in natural conditions ${ }^{[4]}$. The residue in soil is destructive for soil microbial diversity, and the disrupted microbial content will induce the soil-borne disease or other plant diseases ${ }^{[5]}$. What's worse, the MBC residue in underground water or crop surface is threatening to human health, for MBC was toxic for mammalian liver and endocrine ${ }^{[6]}$. Thus, growing concern about the toxicity of MBC had led to the need for new methods on MBC degradation to eliminate MBC contamination in soil, underground water and food surface.

Microbial degradation of MBC has drawn extensive attention due to the effectiveness. Some bacteria such as Nocardioides sp. and Ralstonia sp. had been obtained for $\mathrm{MBC}$ degradation ${ }^{[7,8]}$. The isolation and screening of efficient MBC-degrading microorganisms is available in bioremediation of MBC-contaminated soil, and the addition of microorganisms in soil is favorable for soil microbial diversity and soil improvement. However, the MBC-degrading microorganisms were unable to detoxify MBC-contaminated water and food. In contrast,

Received date: $2018-02-21 \quad$ Accepted date: 2019-03-11

Biographies: Ying Li, $\mathrm{PhD}$, research interest: pesticide degradation, Email: liying0128@qq.com; Miaomiao Chi, Bachelor, research interest: pesticide degradation, Email: 740392248@qq.com.

*Corresponding author: Xizhen $\mathrm{Ge}, \mathrm{PhD}$, research interest: biological control of plant disease. Biochemical engineering college, Beijing Union University, Beijing 100023, China. Tel/Fax: +86-10-52072241, Email: 20057003@ buu.edu.cn. enzymatic bioremediation method is promising due to the high affinity to substrate and the safety to the environment. MBC hydrolyzing enzyme MheI from Microbacterium sp. had been reported for MBC degradation and several mutations had been researched for higher activity ${ }^{[9]}$. Nevertheless, the bioremediation on MBC contaminated water and food was not conducted. Futhermore, the safety of the bacteria isolated in the previous work was unknown, thus they were unable to be directly utilized in soil bioremediation. Thus, food-grade or agricultural used microorganism is needed for soil bioremediation, and a novel hydrolase is essential to detoxify MBC-contaminated food.

Based on the above considerations, this work aim to isolate novel agricultural used bacteria for $\mathrm{MBC}$ degradation, and try to obtain the safe bacteria for degrading MBC in soil and increase soil probiotic diversity at the same time. More importantly, after characterization of the MBC-degrading bacteria, we also purpose to PCR amplify a novel hydrolase coding gene for enzymatic detoxification of MBC contamination (Figure 1).

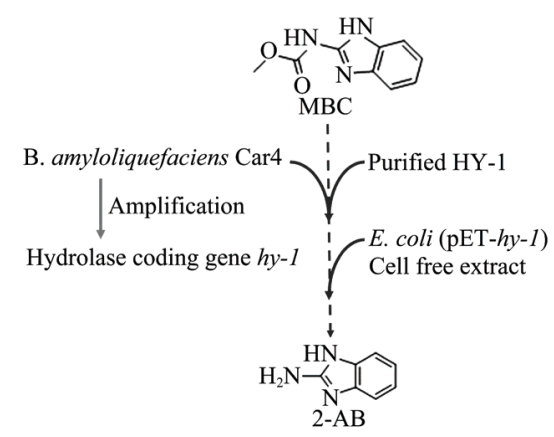

Figure 1 Road map of this work

\section{Materials and methods}

2.1 Isolation and identification of MBC-degrading strain The soil which had been treated with MBC for 5 months at the 
time of sampling was collected from Pinggu District, Beijing, China. To isolate MBC-degrading bacteria, continuous culture was carried out. The MBC-degrading medium content was as following, g/L: $\mathrm{K}_{2} \mathrm{HPO}_{4} 0.5, \mathrm{KH}_{2} \mathrm{PO}_{4} 0.15, \mathrm{MgSO}_{4} 0.3, \mathrm{CaCO}_{3} 0.1$, MBC 0.1. Soil sample $(0.1 \mathrm{~g} / \mathrm{L})$ was added in in the first time of cultivation. The $250 \mathrm{~mL}$ shake flask was used and $100 \mathrm{~mL}$ medium was added. The shake flask was incubated in $30^{\circ} \mathrm{C}$ and agitated at $150 \mathrm{r} / \mathrm{min}$. After incubation for $3 \mathrm{~d}, 1 \mathrm{~mL}$ aliquot from each conical flask was transferred to a new flask containing fresh medium containing only inorganic salts, then was still incubated at $30^{\circ} \mathrm{C}$ with shaking. This process was repeated five times before the final culture was diluted onto solid medium. The solid medium was the same with the enrichment medium except that $15 \mathrm{~g} / \mathrm{L}$ agar powder was added. All plates were incubated at $30^{\circ} \mathrm{C}$ for bacterial isolation. After continuous isolation for more than 5 generations, the pure bacterial cultures that could grow with MBC as carbon source were selected. Then the strain was transferred onto Luria-Bertani (LB) solid medium $(\mathrm{NaCl}, 1 \%$; peptone, $1 \%$; yeast extract, $0.5 \%$, ager powder, $1.5 \%$ ) for preservation. Subsequently, 16S rDNA sequencing was conducted with two universal primers $27 \mathrm{~F}$ and 1492R. DNA sequencing was accomplished in Biomed company Beijing, and the phylogenetic tree was constructed by MEGA 5.0 system.

\subsection{Microbial MBC degradation analysis}

To research MBC degradation ability of the isolated strain Car4, the strain was pre-cultured in LB liquid medium for enrichment. The cultivation was carried out in $250 \mathrm{~mL}$ shake flask containing $100 \mathrm{~mL}$ medium. The temperature was set at $37^{\circ} \mathrm{C}$ and the agitation was set at $200 \mathrm{r} / \mathrm{min}$. After the $\mathrm{OD}_{600}$ value of the medium reached 1.0, $2 \mathrm{~mL}$ of the medium was taken out and the bacteria cell was centrifugally obtained. After washing with sterile $\mathrm{ddH}_{2} \mathrm{O}$ for 2 times, the bacteria cell was then incubated into $100 \mathrm{~mL}$ liquid MBC-degrading medium in $250 \mathrm{~mL}$ shake flask, and MBC concentration was set at $30 \mathrm{mg} / \mathrm{L}$. The cultivation was located in $30^{\circ} \mathrm{C}$ and shaken at $200 \mathrm{r} / \mathrm{min}$. Samples were taken every $24 \mathrm{~h}$ to determine $\mathrm{MBC}$ concentration. Each 1 $\mathrm{mL}$ of the medium was taken out and centrifuged at $12000 \mathrm{r} / \mathrm{min}$ for $10 \mathrm{~min}$, and the supernate was filtered through $0.22 \mu \mathrm{L}$ membrane before injected into HPLC for analysis.

\subsection{Enzymatic MBC degradation analysis}

For enzymatic degradation analysis, cell free extract of $E$. coli overexpressing hy-1 and the purified hydrolase HY-1 were applied to identify MBC degradation. E. coli (pET-hy-1) was cultured in $100 \mathrm{~mL}$ LB medium containing $5 \mu \mathrm{g} / \mathrm{mL}$ kanamycin to keep the plasmid. After cultivation at $37^{\circ} \mathrm{C}$ with $200 \mathrm{r} / \mathrm{min}$ for $12 \mathrm{~h}, 1$ $\mathrm{mmol} / \mathrm{L}$ isopropyl $\beta$-D-thiogalactoside (IPTG) was added into the medium and the temperature was set at $30^{\circ} \mathrm{C}$. Then the shake flask was cultivated for another $3 \mathrm{~h}$ for protein expression. Cell was harvested by centrifugation at $12000 \mathrm{r} / \mathrm{min}$ for $10 \mathrm{~min}$, then $20 \mathrm{mM}$ potassium phosphate buffer $(\mathrm{pH}=7.0)$ was added for resolution of the cell. Ultrasonic disruption of the bacteria was conducted at $100 \mathrm{~W}$ for $5 \mathrm{~min}$ (work $3 \mathrm{~s}$, stop $2 \mathrm{~s}$ ). Subsequently, $0.1 \mathrm{~mL}$ of cell free extract was used for protein determination with Coomassie Bright Blue, and another $0.1 \mathrm{~mL}$ was applied for enzymatic activity analysis or MBC degradation experiment. Cell free extract or purified protein was added into $20 \mathrm{mM}$ potassium phosphate buffer $(\mathrm{pH}=7.0)$ with $5 \mathrm{mg} / \mathrm{L} \mathrm{MBC}$. The reaction mixture was incubated at $37^{\circ} \mathrm{C}$ for $1 \mathrm{~h}$. The remaining $\mathrm{MBC}$ was evaluated by HPLC.

\subsection{Soil bioremediation}

Then MBC degradation in soil was conducted by using the soil collected from the experimental plot of Beijing Union University. The soil was pre-cultured for $3 \mathrm{~d}$ in the incubator to adapt the environment of the incubator. The temperature and the humidity were set at $26^{\circ} \mathrm{C}$ and $60 \%$, respectively. Then difficult concentrations of $\mathrm{MBC}(20-100 \mu \mathrm{g} / \mathrm{g}$ soil) were added and thoroughly mixed into the soil. Samples were taken every $24 \mathrm{~h}$ to identify MBC degradation. To determine the residual MBC in the soil, samples were collected and then dried in the dryer oven for $1 \mathrm{~h} 80^{\circ} \mathrm{C}$. Then $0.1 \mathrm{~g}$ dried soil was dissolved in $500 \mu \mathrm{L}$ $\mathrm{ddH}_{2} \mathrm{O}$. After dissolution and vortex oscillation, the mixer was filtered through $0.22 \mu \mathrm{m}$ membrane before injection into HPLC for $\mathrm{MBC}$ concentration analysis. Enzymatic remediation of MBC in soil was carried out in the similar way. In total $10 \mathrm{mg} E$. coli (pET-hy-1) cell was ultrasonic disrupted and the cell free extract was mixed with $1 \mathrm{~g}$ soil at $30^{\circ} \mathrm{C}$. After cultivation, the remaining $\mathrm{MBC}$ in the soil was measured according to the method above.

\subsection{Fruits bioremediation}

To research the application of the MBC hydrolase in detoxifying $\mathrm{MBC}$ contaminated fruits, cucumbers were used as $\mathrm{MBC}$ contaminated fruit by pre-cultivation of cucumbers and MBC solution. Cucumbers were firstly cut into $3 \mathrm{~cm}$ length fragments before they were incubated in $10 \mathrm{mg} / \mathrm{L} \mathrm{MBC}$ for $3 \mathrm{~min}$. Then the cucumbers were stewed at room temperature for $3 \mathrm{~h}$ to evaporate water, and the surface of dried cucumbers was filled with MBC. Subsequently, enzymatic remediation was conducted and $1 \mathrm{mg} / \mathrm{L}$ purified protein $\mathrm{HY}-1$ was splashed onto experiment group. In parallel, the same volume of sterilized $\mathrm{ddH}_{2} \mathrm{O}$ was added to the control group. To determine $\mathrm{MBC}$ residue on the surface of cucumber, the experimental group and the control group were immersed into $200 \mathrm{~mL}$ water for 10 min separately for completely MBC dissolution (dissolution equilibrium was reached within $6 \mathrm{~min}$ ), and the MBC in water was determined. The initial MBC concentration on surface of cucumbers was set as $100 \%$. All the experiments were conducted for 3 times to calculate the standard deviation. The $\mathrm{MBC}$ concentrations in this study were measured by HPLC.

\subsection{Gene cloning and protein purification}

The coding sequence of the MBC hydrolase derived from the strain Car4 was amplified by PCR. The genomic DNA of strain Car4 was used as the PCR template. The 16S rDNA alignment suggested that Car4 was mostly similar to Bacillus amyloliquefaciens, thus the PCR primers were designed based on the DNA sequence of possible hydrolase gene BSF20_12070. The sequences of the primers were: hy-l-F: ATGTGGANTTGGANAGCNGA $\left.3^{\prime}\right)$ and hy-l-R: (5' TCAANTATACTGNTCTGTAA $\left.3^{\prime}\right)$. The PCR was performed as the following program: $94^{\circ} \mathrm{C}$ for $1 \mathrm{~min}, 30$ cycles of $94^{\circ} \mathrm{C}$ for $15 \mathrm{~s}$, $55^{\circ} \mathrm{C}$ for $20 \mathrm{~s}, 72^{\circ} \mathrm{C}$ for $40 \mathrm{~s}$. The PCR product was separated by gel electrophoresis. The band with the expected size was cut and purified. Then the fragment was ligated into expression vector pET-28a with BamHI and HindIII sites, and the recombinant plasmid was transformed into $E$. coli BL21 (DE3). The recombinant strain was named $E$. coli (pET-hy-1).

For HY-1 purification, the recombinant strain E. coli (pET-hy-1) cultured in $4 \mathrm{~mL} \mathrm{LB}$ medium supplemented with $20 \mu \mathrm{g} / \mathrm{mL}$ kanamycin, at $37^{\circ} \mathrm{C}$ overnight. Cultured E. coli (pET-hy-1) was then transferred into fresh $20 \mathrm{~mL} \mathrm{LB}$ medium at the ratio of $1: 100$ and cultured for another $2 \mathrm{~h}$ at $37^{\circ} \mathrm{C}$, followed by another $3 \mathrm{~h}$ at $30^{\circ} \mathrm{C}$ with $0.5 \mathrm{mM}$ IPTG added. Next, cells were centrifuged and washed for 3 times before they were ultrasonic 
disrupted according to the method above. Cell lysis solution was then centrifuged and the supernatant was used for protein purification. Protein in the supernatant was purified using Nickel chromatographic column of Protein Purification Kit of Beyotime according to the steps. SDS-PAGE was conducted in $12 \%$ polyacrylamide gel, and protein ruler was obtained from TAKARA.

\subsection{Enzyme activity assay}

The enzymatic activity of hydrolase was determined by hydrolyzing $\mathrm{MBC}$ at $30^{\circ} \mathrm{C}$ within $1 \mathrm{~h}$. The reaction mixer was $20 \mathrm{mM}$ potassium phosphate buffer $(\mathrm{pH}=7.0)$ and $25 \mu \mathrm{M} \mathrm{MBC}$. The reaction was initiated by adding the enzyme into the mixturre, and was terminated by incubating in $100^{\circ} \mathrm{C}$ water for $10 \mathrm{~min}$. The remaining MBC was measured by HPLC. One units of enzyme activity was defined as the enzyme required for $1 \mu \mathrm{M} \mathrm{MBC}$ degradation in $1 \mathrm{~h}$.

\subsection{Analytical methods}

MBC concentration was measured in a SHIMADZU LC-20A HPLC system equipped with a $300 \mathrm{~mm} \mathrm{C}_{18}$ column. The mobile phase was consisted by methanol/water/phosphoric acid and the volume ratio was 15:85:0.025. The column temperature was set at $30^{\circ} \mathrm{C}$ and the flow rate was $0.8 \mathrm{~mL} / \mathrm{min}$. The wavelength of the UV detector was set at $280 \mathrm{~nm}$. Metabolites of MBC degradation were detected MS system. Samples were thawed and centrifuged to remove insoluble particles. The supernatants were dried in nitrogen condition and the residues were dissolved in methanol. MS analysis was performed on an API 4000 mass spectrometer under positive-ion turbo ion spray ionization mode.

\section{Results and discussion}

\subsection{Isolation and characterization of $\mathrm{MBC}$-degrading strain}

Bacterial single colony that could grow with $\mathrm{MBC}$ as the sole carbon source was obtained after continuous purification. The $16 \mathrm{~S}$ rDNA sequencing result suggested that the strain belonged to Bacillus genus and it was mostly closed to Bacillus amyloliquefaciens strain YH-5. The strain was named as Car4. The phylogenetic tree was constructed based on 16S rDNA alignment and it was displayed in Figure 2a. It can be inferred that strain Car4 and other B. amyloliquefaciens strains were characterized into different types by the analysis of phylogenetic relationships. In previous researches, MBC-degrading strains were isolated such as Microbacterium and Ralstonia. In contrast, there is only a few literatures reported the MBC-degrading strain that belongs to Bacillus genus ${ }^{[10,11]}$. The advantage of using $B$. amyloliquefaciens over the other strains was that $B$. amyloliquefaciens was a defined agricultural probiotic, meaning that it can be used directly in soil bioremediation ${ }^{[12,13]}$.

The result of MBC degradation by Car4 was displayed in Figure 2b. It can be inferred that Car4 is able to survive by using $\mathrm{MBC}$ as the sole carbon source. After $7 \mathrm{~d}$ cultivation, the $\mathrm{OD}_{600}$ of Car4 reached 0.14 (0.04 g/L cell dry weight), and $30 \mathrm{mg} / \mathrm{L}$ of $\mathrm{MBC}$ was consumed in total. The average degradation rate was $4.3 \mathrm{mg} /(\mathrm{L} \cdot \mathrm{d})$, which is faster than the previously isolated Rhodococcus erythropolis and slower than Ralstonia ${ }^{[7,14]}$. Advantageously, the cultivation cost of Car4 is cheaper than that of the other genus for Bacillus was easier for biomass accumulation with broad substrate utilization spectrum ${ }^{[15,16]}$.

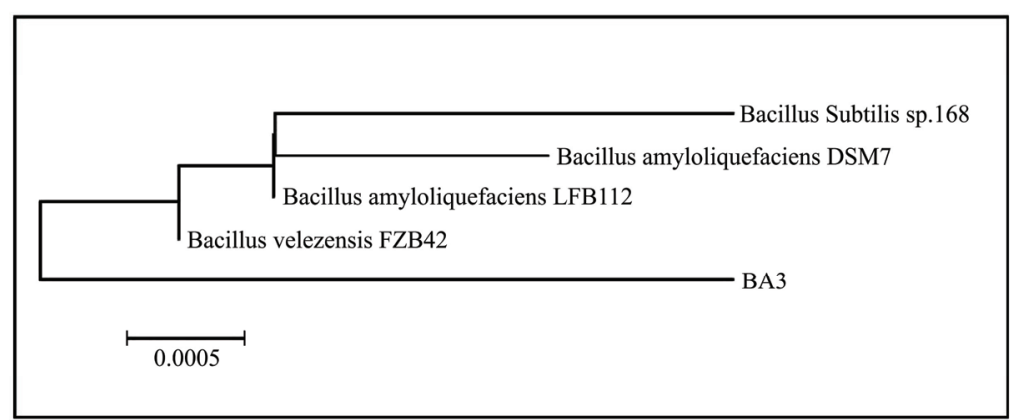

a. Phylogenetic tree of the isolated strain Car4

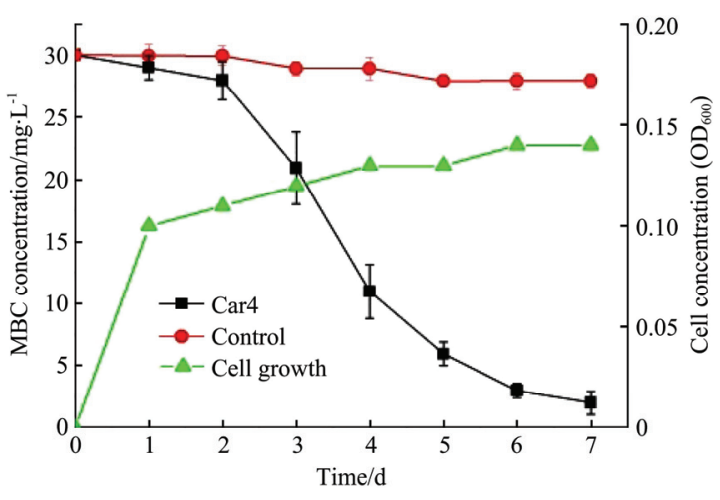

b. MBC degradation ratio and biomass accumulation of Car4

Figure 2 Phylogenetic tree and MBC degradation ratio and biomass accumulation of Car4

\subsection{Cloning, expression and purification of $\mathbf{H Y}-1$}

The primers used for cloning the hydrolase coding sequence in Car4 were designed according to the sequence from $B$. amyloliquefaciens after gene alignment. The coding sequence was obtained by PCR amplification by using genomic DNA of Car4 and the gene was named as hy-1. DNA gel electrophoresis of the PCR product identified that the length of $h y-1$ gene was about 800 bp (Figure 3a). The sequencing result showed that the hy-1 coding sequence had $99 \%$ similarity to the phospholipase coding gene (CP018152.1) from Bacillus amyloliquefaciens strain S499. Subsequently, the hydrolase HY-1 encoded by gene hy-1 was obtained by overexpression. The coding sequence of hy-1 was ligated with expression vector pET-28a $(+)$ with a C-terminal $6 *$ His tag. The expression vector was electro-transformed into $E$. coli BL21 (DE3), and the resulting strain was named as E-HY1. The recombinant E-HY1 strain was cultivated with the induction of $0.5 \mathrm{mM}$ IPTG for $5 \mathrm{~h}$, and a clear IPTG induced band was observed in SDS-PAGE analysis (Figure 3b). The molecular mass of HY-1 was almost $30 \mathrm{kDa}$, which is identical to the calculation based on hy-1 gene sequence. The molecular mass of HY-1 was similar to the other reported MBC-degradation enzymes, belonging to hydrolase family ${ }^{[8,9]}$. Then the HY-1 was purified by Ni-NTA agarose gel and the result was displayed in Figure 3c. The purified HY-1 was successfully obtained through freeze drying.

\subsection{Metabolite characterization and enzyme assay}

To characterize the biodegradation product of HY-1, HPLC and MS analysis were conducted based on the hydrolyzing reaction. The results were displayed in Figure 4. The HPLC analysis of MBC hydrolysis products in Figure 4a indicated that MBC was catalyzed into a novel compound that was eluted at $9.2 \mathrm{~min}$, while the remaining $\mathrm{MBC}$ in the reaction mixer was eluted at $13.2 \mathrm{~min}$. The main peaks of the 2 compounds were both at the same position compared to the standard substances. Moreover, the MS data confirmed the exact molecular weights of the products in Figure $4 \mathrm{~b}$ The fragment ion peaks at $\mathrm{m} / \mathrm{z} 134$ and $\mathrm{m} / \mathrm{z} 192$ were identified as 2-aminobenzimidazole (2-AB) and $\mathrm{MBC}$, respectively. The 
HPLC and MS results showed that HY-1 catalyzed MBC into 2-AB successfully.

The enzymatic activity of HY-1 on MBC was then determined. HPLC data showed that $5 \mu \mathrm{mol} / \mathrm{L} \mathrm{MBC}$ in $100 \mathrm{~mL}$ PBS buffer was completely hydrolyzed within $24 \mathrm{~h}$ when $1 \mathrm{mg}$ cell free extract of E-HY1 was added at $37^{\circ} \mathrm{C}$. When $0.05 \mathrm{mg} / \mathrm{L}$ of the purified HY-1 was added into the same solution, the MBC was completely

from TAKARA, lane 2: E. coli BL21 (pET-28a) vector, lane 3: E. coli BL21 (pET-hy-1)

Figure 3 Identification of $h y-1$ gene and HY-1 protein

degraded in $150 \mathrm{~min}$. The relative enzymatic activities of E-HY1 cell free extract and purified HY-1 were $0.021 \mathrm{U} / \mathrm{mg}$ and $40 \mathrm{U} / \mathrm{mg}$, respectively. The enzymatic activity of HY-1 was slightly higher than the previous reports ${ }^{[9,17]}$. In total, the hydrolyzing results certified that MBC was degraded by HY-1, and enzymatic assay suggested that HY-1 is a proper protein for restoration of MBC-contaminated soil and food.
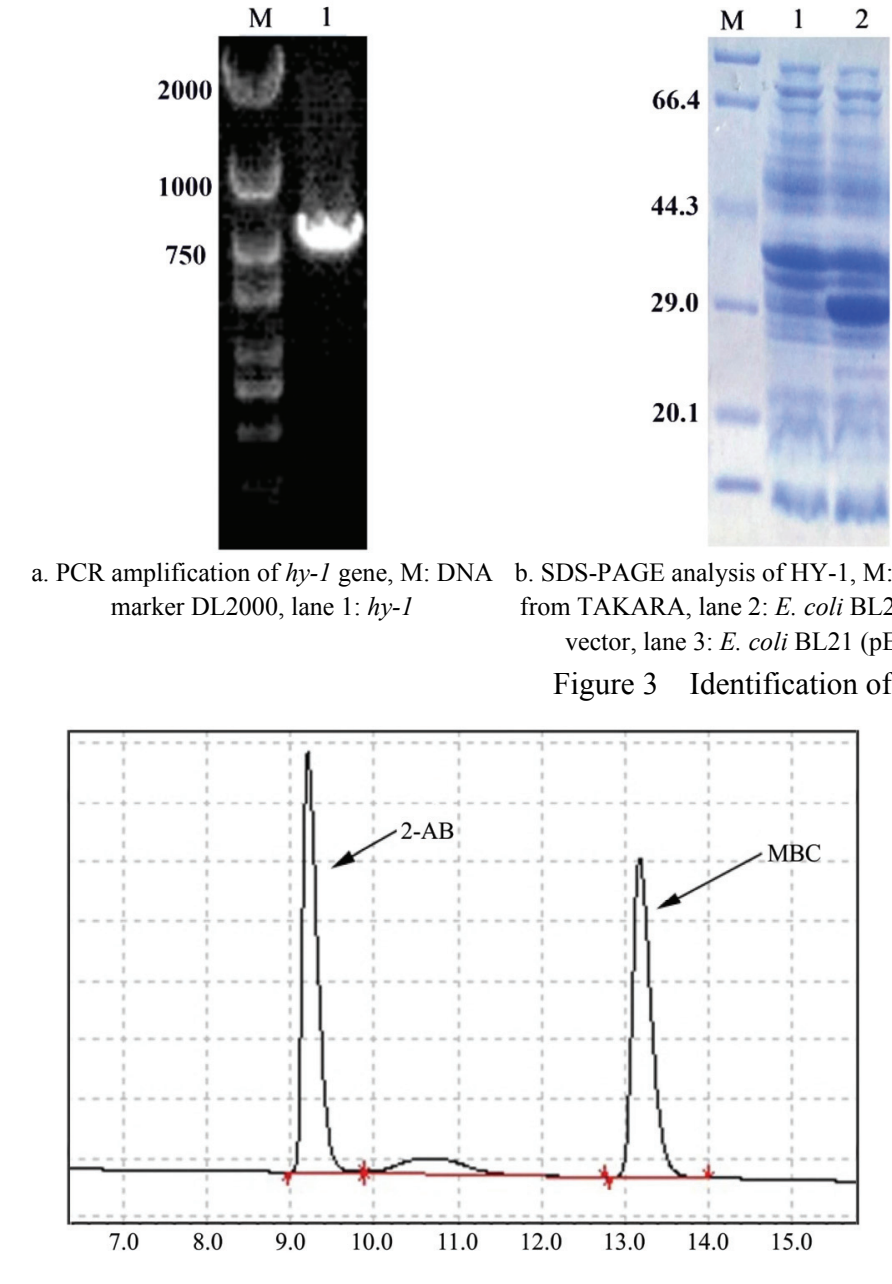

a. PCR amplification of $h y-1$ gene, M: DNA b. SDS-PAGE analysis of HY-1, M: protein ruler marker DL2000, lane 1: $h y-1$ a. HPLC analysis of reaction mixer

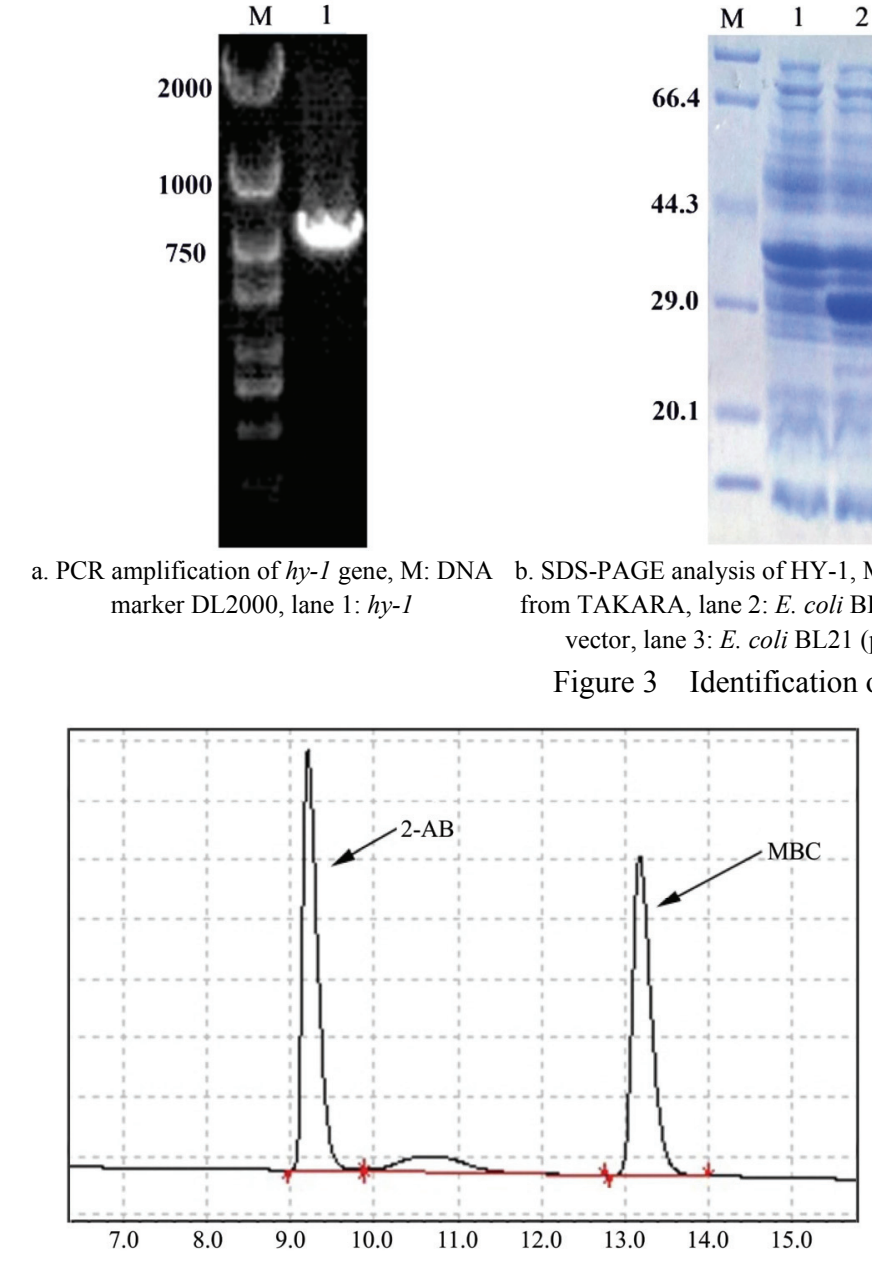

Figure

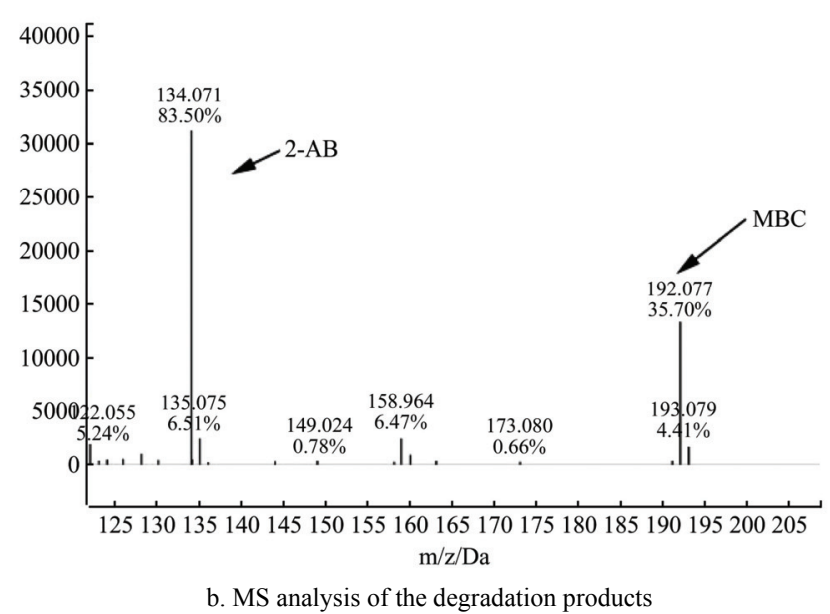

b. MS analysis of the degradation products

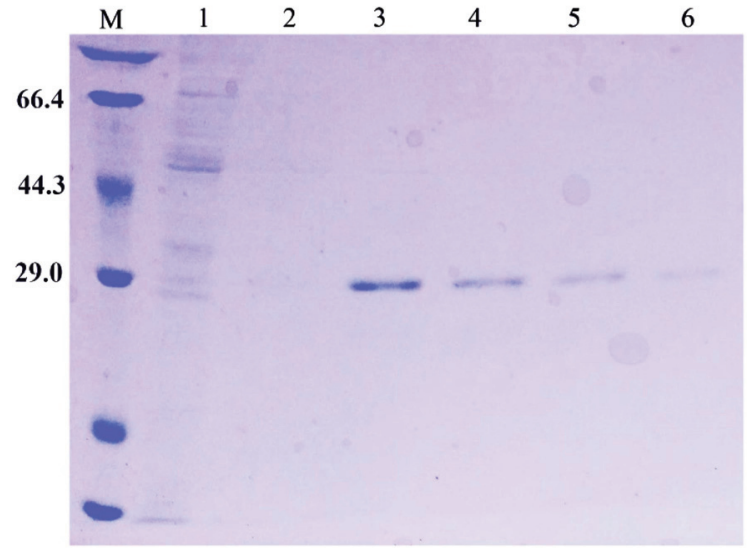

c. HY-1 purification, M: protein ruler from TAKARA, lane 2: washing solution in Ni-NTA, lane 2-6: eluent at different time

\subsection{Soil restoration}

To evaluate the feasibility of strain Car4 and enzyme HY-1 for soil bioremediation, MBC degradation in soil was carried out with either Car4 or cell free extract of E-HY1 added. The degradation results with different original $\mathrm{MBC}$ concentrations were displayed in Figure 5. It can be drawn that $\mathrm{MBC}$ degradation ratios were all accelerated with Car4 or HY-1 crude extract added under various MBC concentrations. When MBC concentrations were $20 \mu \mathrm{g} / \mathrm{g}$ and $50 \mu \mathrm{g} / \mathrm{g}$ in soil, the addition of Car4 and HY-1 crude extract had similar effect on $\mathrm{MBC}$ degradation ratio. In the primary stage within $4 \mathrm{~d}$, the addition of HY-1 crude extract led to the faster degradation of MBC than the addition of bacteria, for the enzyme catalyzed reaction was easier initiated than the bacteria catalyzed reaction. However, the remaining MBC when Car4 added in the following days was lower than HY-1 crude extract added. This indicated that the strain Car4 played an important role in MBC degradation after the adaption to the soil environment. In contrast, the enzyme HY-1 was easily degraded in soil, thus led to the faster degradation within $4 \mathrm{~d}$ and lower degradation after $4 \mathrm{~d}$. Car4 and HY-1 played distinct roles in MBC degradation for bacterial remediation and enzymatic remediation experiments. In all, MBC degradation ratios were both accelerated compared to the control. $20 \mu \mathrm{g} / \mathrm{g}$ and $50 \mu \mathrm{g} / \mathrm{g}$ MBC were completely degraded in $10 \mathrm{~d}$ and $12 \mathrm{~d}$, respectively, while the same effects were reached at $14 \mathrm{~d}$ and $16 \mathrm{~d}$ without Car4 or HY-1 crude extract added.

When the MBC concentrations were $80 \mu \mathrm{g} / \mathrm{g}$ and $100 \mu \mathrm{g} / \mathrm{g}$ in soil, Car4 and HY-1 were more effective in accelerating MBC degradation. The addition of Car4 accelerated MBC degradation obviously, and the remaining $\mathrm{MBC}$ was $10 \%$ lower than the control from 8 day to the end. It can be drawn that the optimum effect by Car4 in soil bioremediation was reached at $80 \mu \mathrm{g} / \mathrm{g}$ MBC concentration, and only $6.19 \mu \mathrm{g} / \mathrm{g}$ was left in the soil at 16 day. When $100 \mu \mathrm{g} / \mathrm{g}$ MBC was added, 36.1 $\mu \mathrm{g} / \mathrm{g}$ MBC was remained in the soil. This was probably due to the bactericidal effect of MBC against Car4 when MBC concentration was $100 \mu \mathrm{g} / \mathrm{g}$, and the cell death of Car4 led to decreased MBC degradation ratio. The addition of HY-1 crude extract also increased MBC degradation ratio, but the accelerated consumption of $\mathrm{MBC}$ was mainly focused on the primary stage before $6 \mathrm{~d}$. Enzymatic remediation was better than bacterial remediation when $\mathrm{MBC}$ concentrations were 
lower. However, the half-life period of enzyme HY-1 was much shorter than Car4, thus led to the faster degradation ratio before $6 \mathrm{~d}$ and slower degradation ratio after $6 \mathrm{~d}$. When $80 \mu \mathrm{g} / \mathrm{g}$ and $100 \mu \mathrm{g} / \mathrm{g}$ of MBC was provided, MBC was completely consumed at 17 th day and 21th day, respectively, which were both faster than
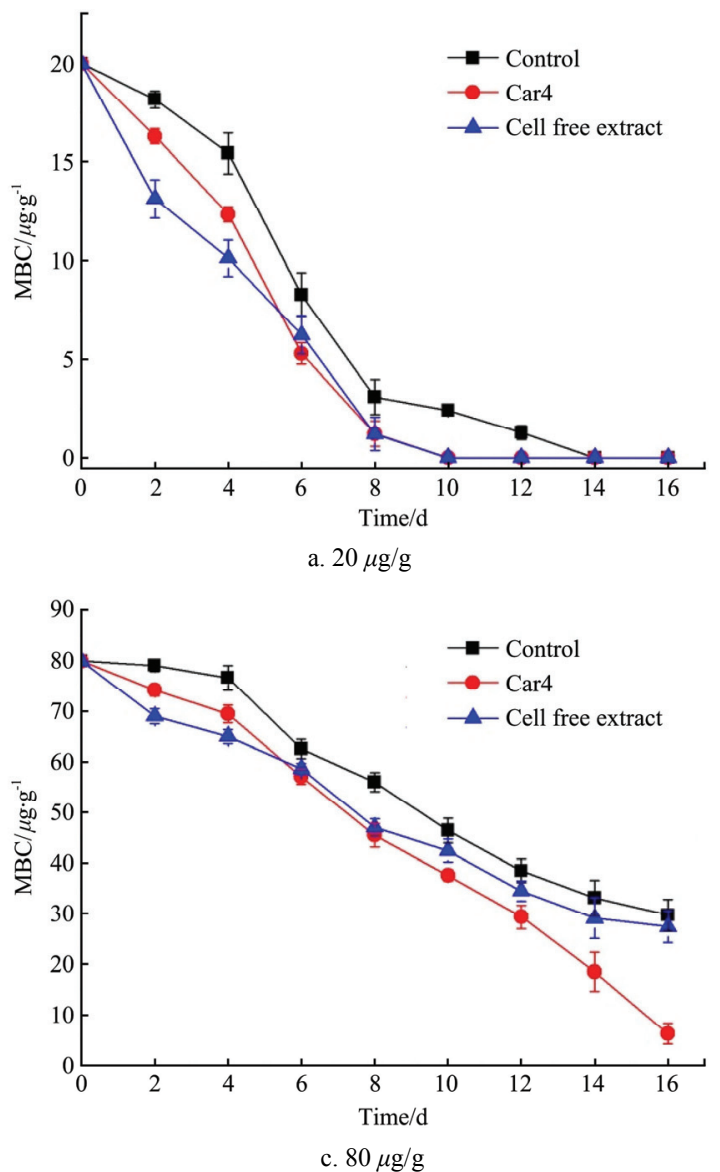

Figure $5 \mathrm{MBC}$ degradation analysis with different $\mathrm{MBC}$ initial concentrations

\subsection{Food restoration}

The cell crude extract of E-HY1 was able to accelerate MBC degradation in soil, thus purified HY-1 was used for bioremediation of MBC-contaminated cucumber. The MBC pre-treated cucumber was applied for remediation, and the results were displayed in Figure 6a. It can be inferred that MBC degradation ratio was increased to a large scale compared to the control. In the end of the experiment, $41.8 \%$ of the original MBC was catalyzed by HY-1, while only $30.5 \%$ of MBC was naturally catalyzed. Enzymatic remediation was certified available in cleaning $\mathrm{MBC}$ residual in food surface, which expanded the

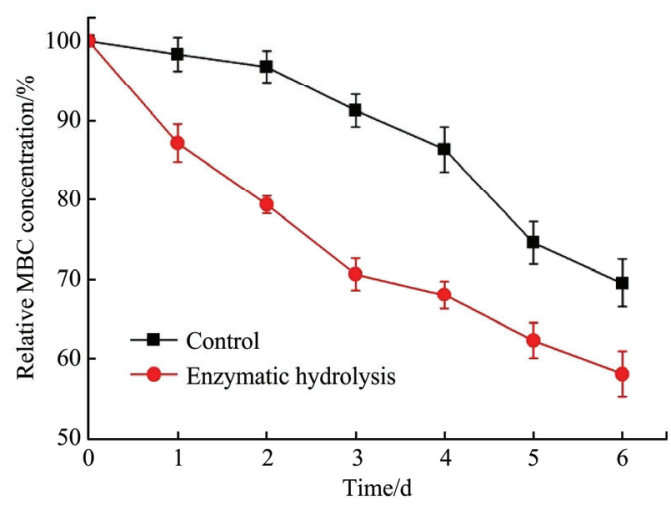

a. MBC degradation on the surface of cucumber the control (20th day and 26th day). This result indicated that enzymatic remediation is feasible for rapid elimination $\mathrm{MBC}$ residue in low-microbe conditions, while bacterial method is suitable for soil remediation because Car4 was able to survive in soil with MBC as carbon source.
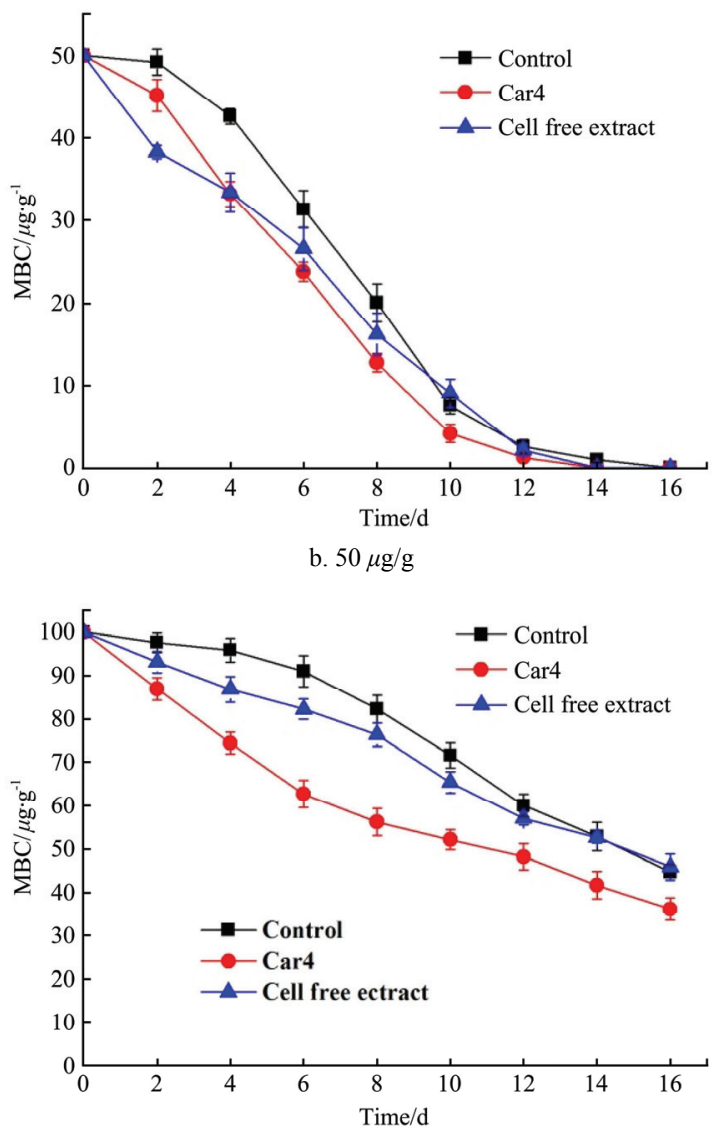

d. $100 \mu \mathrm{g} / \mathrm{g}$

enzymatic bioremediation of pesticide contaminations ${ }^{[23]}$. It can be drawn that the most obvious difference between experimental group and the control group was located in the initial stage of bioremediation, meaning that MBC degradation was accelerated greatly from the 1 st day to the 4 th day. However, from the 4 th day to the end, the $\mathrm{MBC}$ degradation ratios of the 2 groups were tend to be similar. The reason was mainly resulted by the natural degradation of HY-1. In all, the purified HY-1 efficiently accelerated the degradation of MBC in the surface of fruit especially in the initial $4 \mathrm{~d}$, and this is the first report on enzymatic bioremediation of MBC-contaminated food.

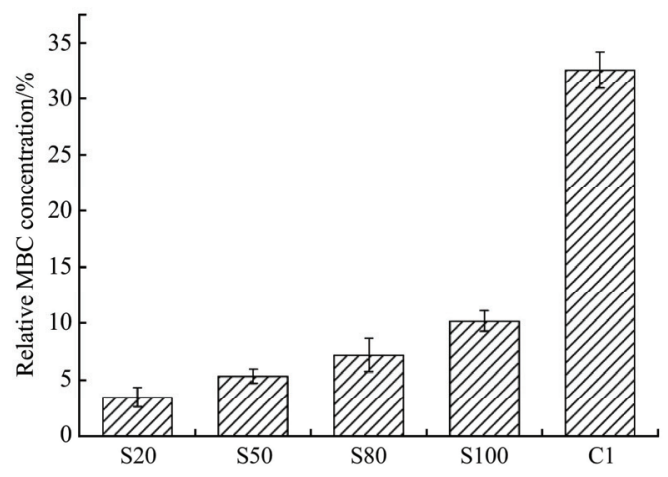

b. Relative 2-AB concentrations in soil and cucumber surface

Figure $6 \mathrm{MBC}$ degradation on the surface of cucumber and relative 2-AB concentrations in soil and cucumber surface 


\section{Discussion}

MBC contamination in soil and food is difficult to be cleaned because MBC was rarely soluble in water. Microbial and enzymatic remediation provided novel methods for $\mathrm{MBC}$ degradation and restoration. However, the efficiencies of these methods were restricted due to the low enzyme activity and microbial degradation rate. In contrast, the isolated Car4 in this work was able to efficiently degrade MBC. Moreover, Car4 belongs to Bacillus genus, which is also an agricultural probiotics used in promoting plant growth. More importantly, a newly isolated hydrolase HY-1 was obtained and heterogeneously expressed in E. coli, and HY-1 functioned efficiently in removing $\mathrm{MBC}$ residue in the surface of fruits and vegetables. Compared to the previous research, both the microbial method and enzymatic method were competent used in bioremediation of $\mathrm{MBC}$ contamination.

The maximum MBC degradation ratio of Car 4 was $4.1 \mu \mathrm{g} /(\mathrm{g} \cdot \mathrm{d})$. Compared to the other isolated bacteria such as Ralstonia and Altermria alternata $^{[7,18]}$, Car4 exhibited higher efficiency in MBC degradation in soil. Interestingly, when used for agricultural applications, Car4 was more suitable for soil bioremediation because bacteria that belong to Bacillus genus were safe to the environment ${ }^{[19]}$. Some strains of Bacillus even facilitates as plant growth accelerant or antifungal biopesticide ${ }^{[20-22]}$. Therefore, the application of Car4 combined with several Bacillus strains is feasible in $\mathrm{MBC}$ degradation and probiotic enrichment ${ }^{[10,11]}$. However, MBC functions as an antibiotic in controlling plant disease, and bacterial bioremediation is invalid when MBC concentration is high. Thus, the enzymatic bioremediation is feasible for bioremediation with high MBC concentration when bacterial method is ineffective. Cell crude extract successfully accelerated MBC degradation in soil. More importantly, the industrial production of cell crude extract was economical viable. The main disadvantage for enzymatic bioremediation is the short half-life time of the enzyme in soil. In conclusion, the cooperation of enzymatic bioremediation and bacterial bioremediation methods are able to restore the MBC-contaminated soil under different MBC concentrations.

However, there still exist problems in enzymatic remediation by HY-1. Although MBC degradation was accelerated, 2-AB was still remained on the food surface. In Figure 6b, the relative $2-A B$ content in soil and food surface were displayed. The remaining $2-\mathrm{AB}$ in soil was much lower than that on food surface. With the increased original $\mathrm{MBC}$ concentrations in soil, the relative 2-AB contents were also increased slightly. When $100 \mu \mathrm{g} / \mathrm{g}$ MBC was added, $10.2 \%$ of $2-\mathrm{AB}$ was remained. However, the residual $2-\mathrm{AB}$ on the cucumber surface at 6 days was $32.6 \%$, which also led to serious food contamination because $2-\mathrm{AB}$ was also toxic to human health. It can be deduced that $2-\mathrm{AB}$ was easier consumed by soil microbes, leading to lower $2-\mathrm{AB}$ residue. In comparison, the microbial diversity on food surface was much less than in the nutritious soil ${ }^{[24]}$. MBC on food surface was degraded by HY-1, but the catalytic product 2-AB was unable to be cleaned by the enzyme. Collectively, HY-1 was a novel enzyme for bioremediation that accelerated $\mathrm{MBC}$ degradation. On the other hand, a mixer of functional enzymes was feasible in bioremediation of MBC-contaminated food thoroughly.

\section{Conclusions}

In this work, a novel MBC-degrading bacterial Car4 which belongs to Bacillus genus was isolated. A MBC-hydrolyzing enzyme HY-1 from Car4 was obtained and characterized. MS data identified the catalyzing product of HY-1 as 2-AB. Then Car4 and HY-1 were applied for bioremediation of $\mathrm{MBC}$ contamination in soil and food surface. Soil MBC degradation was accelerated with either Car4 or cell crude extract of HY-1 added. Finally, purified HY-1 was applied to restore MBC-contaminated cucumber. In total $41.8 \%$ of the original MBC was degraded within $6 \mathrm{~d}$ experiment and more than $10 \%$ of the $\mathrm{MBC}$ residue on the food surface was degraded compared to the control. In all, this work provided a new bioremediation method on $\mathrm{MBC}$ or other pesticide contamination.

\section{Acknowledgements}

This work was financially supported by Joint Funding of Beijing Municipal Natural Science Foundation-Beijing Municipal Education Commission (KZ201911417049), National Key R\&D Program of China (2017YFD0201105) and Premium Funding Project for Academic Human Resources Development in Beijing Union University (BPHR2017DZ07).

\section{[References]}

[1] Boudina A, Emmelin C, Baaliouamer A, Grenier-Loustalot M F, Chovelon J M. Photochemical behaviour of carbendazim in aqueous solution. Chemosphere, 2003; 50(5): 649-655.

[2] Wang X, Song M, Wang Y, Gao C. Response of soil bacterial community to repeated applications of carbendazim. Ecotoxicology \& Environmental Safety, 2012; 75(1): 33-39.

[3] Mazellier P, Leroy É, Laat J D, Legube B. Degradation of carbendazim by $\mathrm{UV} / \mathrm{H}_{2} \mathrm{O}_{2}$ investigated by kinetic modelling. Environmental Chemistry Letters, 2003; 1(1): 68-72.

[4] Moser T, van Gestel C A, Jones S E, Koolhaas J E, Rodrigues J M, Römbke J. Ring-testing and field-validation of a terrestrial model ecosystem (TME)-an instrument for testing potentially harmful substances: effects of carbendazim on enchytraeids. Ecotoxicology, 2004; 13(1-2): 29-42.

[5] Arora S, Mukherjee I, Trivedi T P. Determination of pesticide residue in soil, water and grain from IPM and Non-IPM field trials of rice. Bulletin of Environmental Contamination \& Toxicology, 2008; 81(4): 373-376.

[6] Selmanoglu G, Barlas N, Songur S, Kockaya E A. Carbendazim-induced haematological, biochemical and histopathological changes to the liver and kidney of male rats. Human \& Experimental Toxicology, 2001; 20(12): 625-630.

[7] Zhang G S, Jia X M, Cheng T F, Ma X H, Zhao Y H. Isolation and characterization of a new carbendazim-degrading Ralstonia sp. strain. World Journal Of Microbiology \& Biotechnology, 2005; 21(3): 265-269.

[8] Pandey G, Dorrian S, Russell R, Brearley C, Kotsonis S, Oakeshott J. Cloning and biochemical characterization of a novel carbendazim (Methyl-1H-Benzimidazol-2-ylcarbamate)-Hydrolyzing esterase from the newly isolated Nocardioides sp strain SG-4G and its potential for use in enzymatic bioremediation. Applied \& Environmental Microbiology, 2010 76(9): 2940-2945.

[9] Lei J, Wei S, Ren L, Hu S, Chen P. Hydrolysis mechanism of carbendazim hydrolase from the strain Microbacterium sp. djl-6F. Journal of Environmental Sciences, 2017; 54(4): 171-177.

[10] Salunkhe V P, Sawant I S, Banerjee K, Wadkar P N, Sawant S D, Hingmire $\mathrm{S}$ A. Kinetics of degradation of carbendazim by B. subtilis strains: possibility of in situ detoxification. Environmental Monitoring \& Assessment, 2014; 186(12): 8599-8610.

[11] Zhang L Z, Qiao X W, Ma L P, Wang J L, Pan X L. Influence of environmental factors on degradation of carbendazim by bacillus pumilus strain NY97-1. International Journal of Environment \& Pollution, 2009; 38(3): 309-317.

[12] Das S, Mishra J, Das S K, Pandey S, Rao D S, Chakraborty A, et al. Investigation on mechanism of $\mathrm{Cr}(\mathrm{VI})$ reduction and removal by Bacillus amyloliquefaciens, a novel chromate tolerant bacterium isolated from chromite mine soil. Chemosphere, 2014; 96(2): 112-121. 
[13] Das S, Pandey S, Pradhan S K, Sudarshan M, Chakraborty A, Thatoi H N. Genomic analysis and comparative hexavalent chromium reduction potential of predominant bacillus species isolated from chromite mine soil. Journal of Soil Contamination, 2015; 24(2): 206-221.

[14] Holtman M A, Kobayashi D Y. Identification of Rhodococcuserythropolis isolates capable of degrading the fungicide carbendazim. Applied Microbiology \& Biotechnology, 1997; 47(5): 578-582.

[15] Krispin O, Allmansberger R. The Bacillus subtilis AraE protein displays a broad substrate specificity for several different sugars. Journal of Bacteriology, 1998; 180(12): 3250-3252.

[16] Goyal N, Gupta J K, Soni S K. A novel raw starch digesting thermostable $\alpha$-amylase from Bacillus sp. I-3 and its use in the direct hydrolysis of raw potato starch. Enzyme \& Microbial Technology, 2005; 37(7): 723-734.

[17] Zhang J, Yin J G, Hang B J, Cai S, He J, Zhou S G, et al. Cloning of a novel arylamidase gene from Paracoccus sp. strain FLN-7 that hydrolyzes amide pesticides. Appl Environ Microbiol, 2012; 78(14): 4848-4855.

[18] Yarden O, Salomon R, Katan J, Aharonson N. Involvement of fungi and bacteria in enhanced and nonenhanced biodegradation of carbendazim and other benzimidazole compounds in soil. Canadian Journal of Microbiology, 1990; 36(1): 15-23.
[19] Guo X, Li D. Screening of Bacillus strains as potential probiotics and subsequent confirmation of the in vivo effectiveness of Bacillus subtilis MA139 in pigs. Antonie Van Leeuwenhoek, 2006; 90(2): 139-146.

[20] Nautiyal C, Srivastava S, Chauhan P, Seem K, Mishra A, Sopory S. Plant growth-promoting bacteria Bacillus amyloliquefaciens NBRISN13 modulates gene expression profile of leaf and rhizosphere community in rice during salt stress. Plant Physiology \& Biochemistry, 2013; 66(5): 1.

[21] Chen X, Koumoutsi A, Scholz R, Eisenreich A, Schneider K, Heinemeyer I, et al. Comparative analysis of the complete genome sequence of the plant growth-promoting bacterium Bacillus amyloliquefaciens FZB42. Nature Biotechnology, 2007; 25(9): 1007-1014.

[22] Cui T B, Chai H Y, Jiang L X. Isolation and partial characterization of an antifungal protein produced by Bacillus licheniformis BS-3. Molecules, 2012; 17(6): 7336-7347.

[23] Sutherland T D, Horne I, Weir K M, Coppin C W, Williams M R, Selleck $\mathrm{M}$, et al. Enzymatic bioremediation: from enzyme discovery to applications. Clinical \& Experimental Pharmacology \& Physiology, 2004; 31(11): 817-821.

[24] Pace N R. A molecular view of microbial diversity and the biosphere. Science, 1997; 276(5313): 734-740 